\title{
Delayed Hemorrhage from Gastroduodenal Artery Pseudoaneurysm following Endoscopic Ultrasound-Guided Fine Needle Aspiration of Pancreatic Head Mass
}

\author{
Young Jae Doo, Seung Goun Hong \\ Department of Internal Medicine, SAM Anyang Hospital, Anyang, Korea
}

Endoscopic ultrasound-guided fine needle aspiration (EUS-FNA) is a well-established procedure for the diagnosis of pancreatobiliary disease. Serious complications such as perforation, pancreatitis, hemorrhage, and sepsis are rarely reported. To our knowledge, delayed hemorrhage after EUS-FNA is very rare and hemorrhage from iatrogenic pseudoaneurysm has yet to be reported. We report a case of delayed hemorrhage from gastroduodenal artery pseudoaneurysm, which developed after EUS-FNA of a solid pancreatic lesion. A 68-year-old man presented with tarry stool 10 days after EUS-FNA of a $1.5 \mathrm{~cm}$-sized pancreatic head mass. Abdominal computed tomography showed a $2-\mathrm{cm}$-sized intensely enhancing round lesion near pancreatic head. EUS-FNA was negative for malignancy. The patient refused admission for further evaluation. Twelve days later, he reported to the emergency room with persistent tarry stool. Angiography showed a gastroduodenal artery pseudoaneurysm. Subsequent coil embolization resulted in successful hemostasis. The patient underwent pylorus-preserving pancreaticoduodenectomy and was diagnosed with stage IIB pancreatic cancer.

Korean J Pancreas Biliary Tract 2018;23(4):165-171

Keywords: Gastrointestinal hemorrhage, Pancreatic neoplasm, Endoscopic ultrasound-guided fine needle aspiration, Pseudoaneurysm, Gastroduodenal artery

\author{
Received Mar. 24, 2018 \\ Revised Jun. 8, 2018 \\ Accepted Jun. 11, 2018
}

Corresponding author : Seung Goun Hong Department of Internal Medicine, SAM Anyang Hospital, 9 Samdeok-ro, Manan-gu, Anyang 14030, Korea

Tel. +82-31-467-9114 Fax. +82-31-449-0151

E-mail; permi@naver.com

ORCID: https://orcid.org/0000-0001-6841-235X

This is an Open Access article distributed under the terms of the Creative Commons Attribution Non-Commercial License (http:// creativecommons.org/licenses/by-nc/3.0/) which permits unrestricted non-commercial use, distribution, and reproduction in any medium, provided the original work is properly cited.

Copyright $\odot 2018$ by The Korean Journal of Pancreas and Biliary Tract

\section{INTRODUCTION}

The safety of endoscopic ultrasound-guided fine needle aspiration (EUS-FNA) has been widely acknowledged and applied in the diagnosis of pancreatobiliary diseases.
Adverse events related to EUS-FNA including infection, bleeding, perforation, pancreatitis were relatively rare within a variable range less than $2.5 \%$ and were marginally higher in prospective than in retrospective studies. ${ }^{1}$ In a recent prospective study of adverse events of EUS-FNA, puncture of 
cystic lesions was similarly complicated in solid masses compared with previous studies. ${ }^{2}$ Severe hemorrhage associated with the procedure was rarely reported. ${ }^{3}$ In spite of the safety, the indication is based on the risk-benefit analysis for patient management and in balancing complications and benefits of diagnostic yield. ${ }^{4,5}$ Most reported bleeding events after EUSFNA occurred within a few days. Delayed hemorrhage associated with iatrogenic pancreatic pseudoaneurysm after EUS-FNA was not reported until recently to our knowledge. We recently experienced a case of delayed severe bleeding after 3 weeks following the EUS-FNA procedure.

\section{CASE}

A 68-year-old male patient presented with a 7-day history of yellow skin and vague abdominal pain and an approximately 15-mm hypodense mass in the pancreatic head on abdominal computed tomography (CT) from other hospital. The patient's medical history indicated diabetes mellitus diagnosed 10 years ago and grade 3 chronic kidney disease 2 years ago. Laboratory findings were as follows: serum hemoglobin $11.3 \mathrm{~g} / \mathrm{dL}$, aspartate transaminase (AST) $72 \mathrm{U} / \mathrm{L}$, alanine transaminase (ALT) $117 \mathrm{U} / \mathrm{L}$, alkaline phosphatase $900 \mathrm{U} / \mathrm{L}$, gamma-glutamyl transferase $735 \mathrm{U} / \mathrm{L}$, total bilirubin of $2.5 \mathrm{mg} / \mathrm{dL}$, amylase/lipase 54/24.4 U/L, CA19-9 $540 \mathrm{U} / \mathrm{mL}$. We performed EUS-FNA with 22 gauge (G) ProCore needle (Cook Endoscopy, Winston Salem, NC, USA) via transduodenal route with 2 passes for the pancreatic head mass and slowpull technique and then subsequently endoscopic retrograde cholangiopancreatography (ERCP). The total procedure time was approximately 40 minutes. During ERCP, a cholangiogram after minor biliary sphincterotomy showed mildto-moderate dilation of common bile duct (CBD) without definite distal bile duct stricture and no pancreatogram was obtained. Bile duct biopsy at distal CBD with brush cytology (Boston Scientific, Natick, MA, USA) was performed. Two $10 \mathrm{~cm} 7 \mathrm{Fr}$ double pigtail plastic stents (Zimmon, Cook Medical, Bloomington, IN, USA) were inserted for biliary decompression. EUS showed an approximately $15 \mathrm{~mm}$ illdefined heterogeneous hypoechoic mass without prominent or tortuous intratumoral and peritumoral vascularity in pancreatic head (Fig. 1). During the two passes of EUSFNA, the cytological and histological specimens obtained were placed on a slide for quick visual inspection. The expelled bloody worm-like specimens appeared adequate upon gross visual inspection. The patient exhibited no specific symptoms after the procedure and passed a small amount of dark green-colored stool once. The follow-up serum hemoglobin level was similar compared with the baseline and the patient discharged the next day after the procedure. During the next visit to the outpatient clinic 10 days after discharge. EUSFNA of the pancreatic head mass was negative for malignancy. Biopsy and brush cytology of distal CBD were also negative for malignancy. A follow-up abdominal CT on that day was performed because of a single episode of tarry stool at home. It showed a pseudoaneurysm and minor fluid collection near pancreatic head (Fig. 2A). Although hospital admission was recommended, the patient refused and went home. However, he revisited the emergency center with complaints of abdominal pain and recurrent melena 22 days after the EUS-FNA. His vital signs were as follows: blood pressure of 100/50 $\mathrm{mmHg}$, heart rate of 112 beats/min,

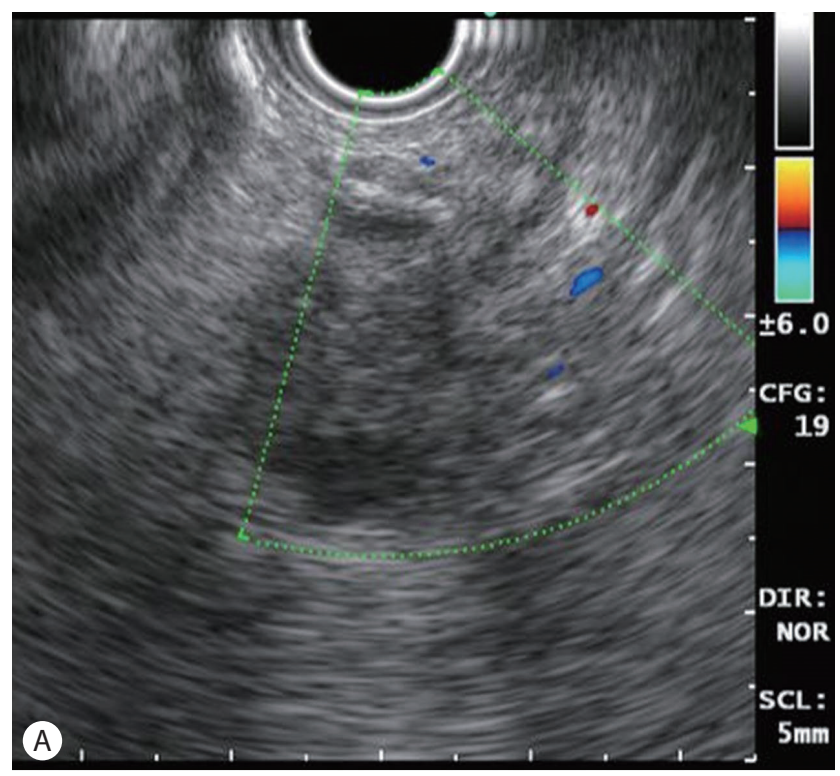

Fig. 1. Endoscopic ultrasound showed an approximately $15 \mathrm{~mm}$-sized ill-defined heterogeneous hypoechoic mass without prominent or tortuous intratumoral and peritumoral vascularity in the pancreatic head. 
respiratory rate of $24 / \mathrm{min}$, and body temperature of $36.1^{\circ} \mathrm{C}$. The laboratory findings were as follows: white blood cell count of $16,000 / \mathrm{mm}^{3}$, hemoglobin of $7.5 \mathrm{~g} / \mathrm{dL}$, platelets of $242,000 /$ $\mathrm{mm}^{3}$, AST of $153 \mathrm{U} / \mathrm{L}$, ALT of $305 \mathrm{U} / \mathrm{L}$, total bilirubin of 1.9 $\mathrm{mg} / \mathrm{dL}$, amylase of $65 \mathrm{U} / \mathrm{L}$, and lipase of $38 \mathrm{U} / \mathrm{L}$. Subsequently, the patient was admitted to an intensive care unit and received transfusion of two units of packed erythrocytes and four units of fresh frozen plasma. ERCP showed large hematoma formation with bleeding from major ampulla, which was attributed to rupture of a previous pancreatic pseudoaneurysm, suggesting hemosuccus pancreaticus (Fig. $3 \mathrm{~A})$. The cholangiogram showed moderate dilation of CBD with two biliary plastic stents in-situ and pancreatogram was not obtained (Fig. 3B). To stop further bleeding from ampullary orifice, a $8-\mathrm{cm}$ biliary covered metal stent (Standard Sci Tech, Seoul, Korea) was inserted without removal of the biliary plastic stents 2 days after admission (Fig. 3C). After the procedure, the interval of bleeding episodes was mildly
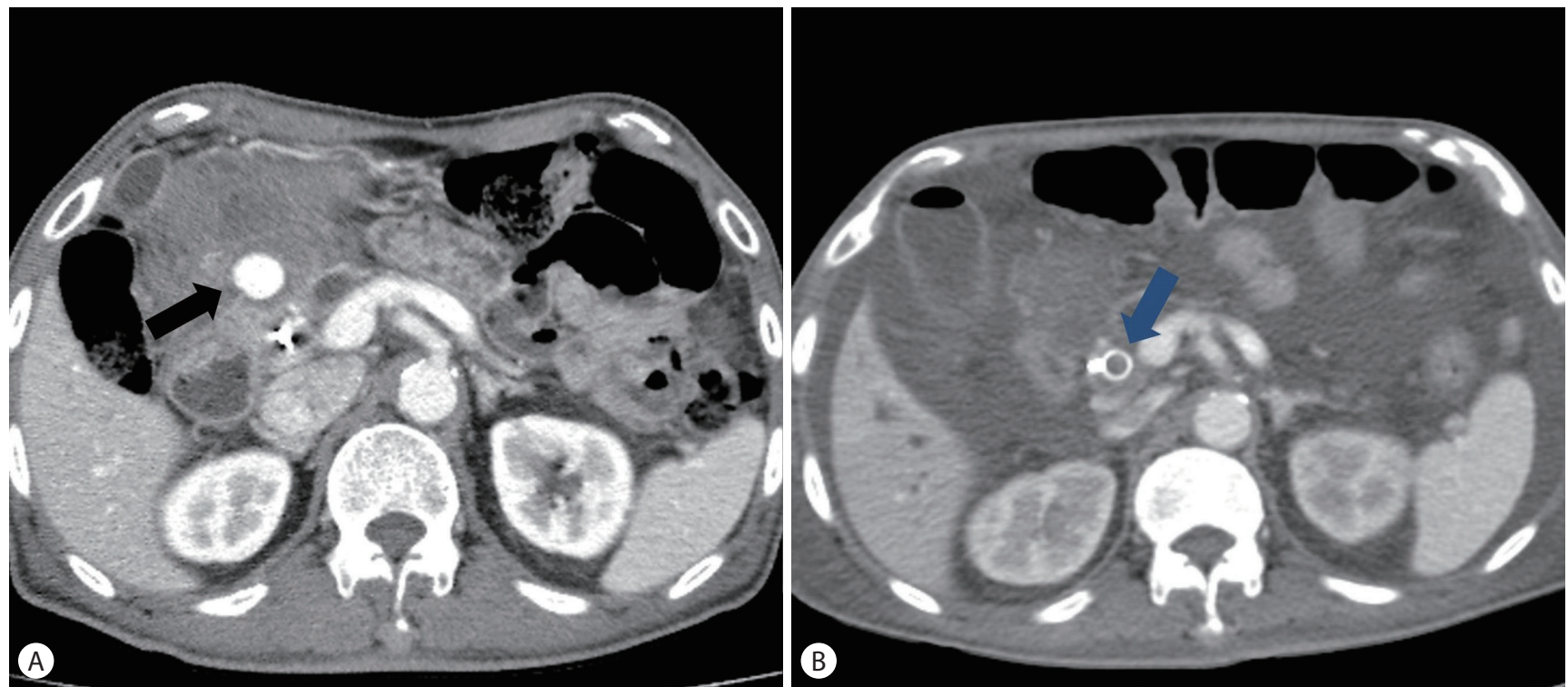

Fig. 2. Abdominal computed tomography. (A) The sagittal image obtained 10 days after endoscopic ultrasound-guided fine needle aspiration showed a $2 \mathrm{~cm}$-sized intensely enhancing round lesion in the pancreatic head (black arrow). (B) Abdominal computed tomography conducted 5 days after endoscopic placement of biliary metal stent (blue arrow) demonstrated the disappearance of the $2 \mathrm{~cm}$-sized intensely enhancing round lesion. However, a large amount of ascites developed.
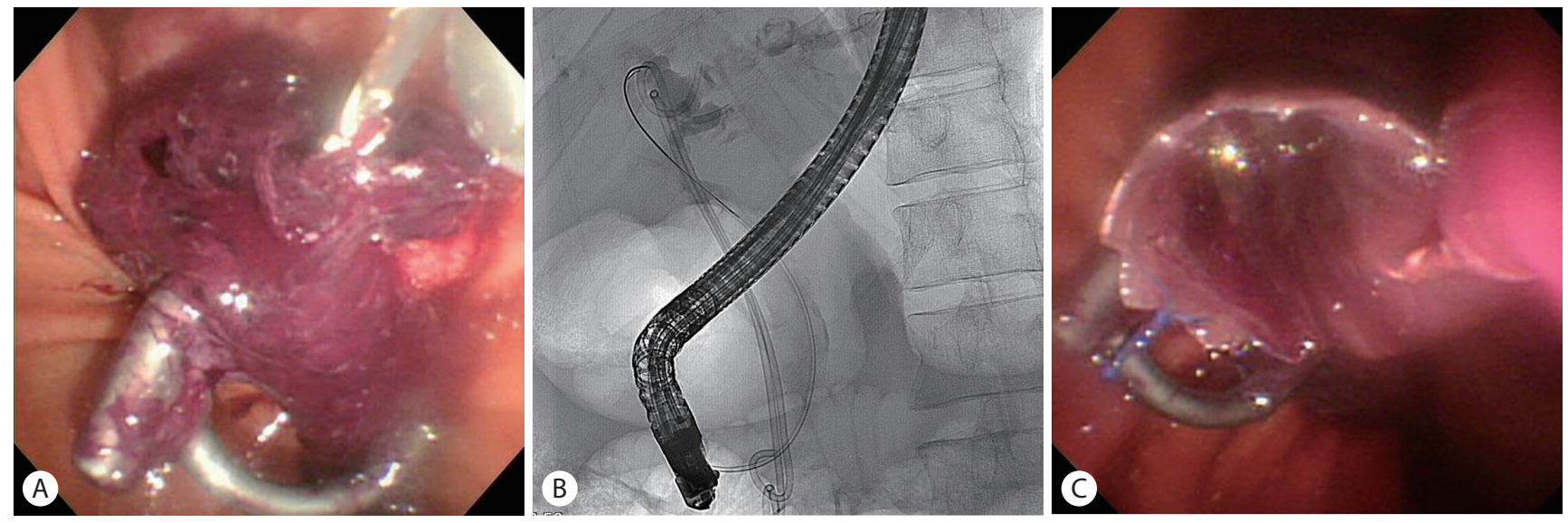

Fig. 3. Endoscopic retrograde cholangiography findings. (A) Endoscopy showed large hematoma formation with partial bleeding from major ampulla. (B) Cholangiogram showed moderate dilation of common bile duct with two biliary plastic stents in-situ. (C) To stop further bleeding from the ampullary orifice, an 8-cm biliary covered metal stent was inserted without removal of the biliary plastic stents. 
increased, despite intermittent and recurrent bleeding. Followup CT taken 5 days after insertion of biliary metal stent revealed an inconspicuous previous pseudoaneurysm in the pancreatic head (Fig. 2B), although bleeding with low serum hemoglobin level continued. Therefore, transfemoral angi- ography and arterial embolization were performed (Fig. 4), which successfully controlled the patient's severe bleeding. Despite the negative EUS-FNA and biopsy findings, surgical treatment had been strongly recommended for the pancreatic head mass given obstructive jaundice, increased level of
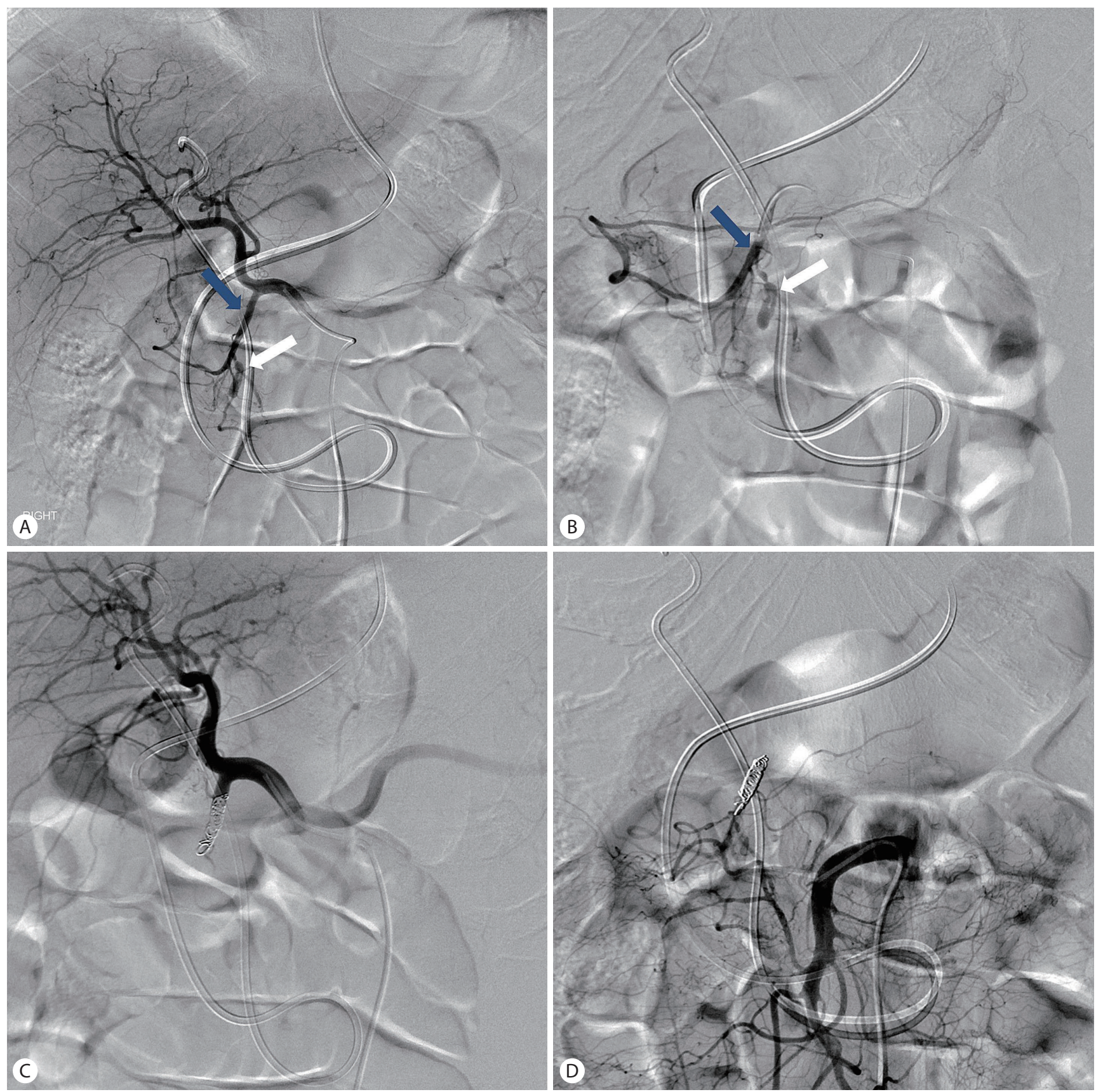

Fig. 4. Angiographic findings via femoral artery. (A) Contrast injection into the common hepatic artery showed a pseudoaneurysm (white arrow) in a branch of the gastroduodenal artery (blue arrow). (B) Selective injection through the gastroduodenal artery (blue arrow) demonstrated similar findings (white arrow). (C) Coil embolization of the gastroduodenal artery stopped the distal flow. (D) Angiography through the superior mesenteric artery showed collateral flow to the distal area of the embolized artery. 
CA19-9 and imaging findings consistent with pancreatic malignancy. The patient underwent pylorus-preserving pancreaticoduodenectomy. The final pathology showed poorly differentiated pancreatic adenocarcinoma, stage IIB. The patient declined adjuvant chemotherapy because of overall deterioration in the general condition after surgery.

\section{DISCUSSION}

Rapid technological advances to improve the diagnostic yield in the field of EUS have led to the development of EUSFNA as a well-established needle-guided tissue sampling technique for patient management, entailing differentiation between benign and malignant lesions, staging of cancer, generation of histological evidence before chemotherapy with/without radiotherapy or surgery. ${ }^{6}$ However, EUS-FNA is still a challenge and special training is recommended with a prolonged learning curve. The American Society for Gastrointestinal Endoscopy suggests that competency can be achieved after a minimum of 150 supervised cases involving 75 pancreatobiliary and 50 EUS-FNA procedures. Currently, 25 supervised EUS-FNA procedures for pancreatic tumor are considered reasonable.

Though the overall rate of complication was very low (approximately $1 \%$ ) in a recent systematic review of EUS-FNA with post-procedural pain (34\%) and pancreatitis (33\%) being the most frequent, followed by bleeding (13\%) and fever episodes $(11 \%){ }^{8}$ The complication rate was more frequent with EUS-FNA of cystic compared with solid lesions. However, recent studies reported that the complication rate for cystic lesions was comparable to that of solid lesions and the rate of severe complications such as perforation, infection or hemorrhage is extremely rare and the overall mortality rate was near $0.2 \%{ }^{2,4,8}$ Periprocedural planning based on a comprehensive review of the clinical records and imaging studies can minimize the complications.

Fortunately, most of the post-procedural bleeding is selflimited and resolved within a few days. However, prevention of bleeding is vital, and the possible risk factors include the number of needle passes, needle size, intervening large vessel or vascularity of target lesion, intake of antithrombotic or non-steroidal anti-inflammatory drugs, and combined coagulopathy. Bleeding can be avoided by meticulous and deliberate selection of the needle path without traversing or injuring the large vessels in tumor and peritumoral lesions, and compressible moderate-to-large vessels surrounding the gastrointestinal tract using Doppler imaging. Minimization of the number of needle passes and to-and-fro movements was desirable with adequate sampling. The procedure can be delayed reasonably in patients treated with antithrombotic drugs, with a high risk of bleeding, although robust guidelines have yet to be established. ${ }^{1,9-11}$

Two risk factors including small size of tumor and lowvolume in our case warranted EUS-FNA using a 22 G ProCore needle with two needle passes and approximately 10 to-and-fro movements with the aid of Doppler imaging for approximately $15 \mathrm{~mm}$ small pancreatic tumor. ${ }^{7,9}$ In addition, we have already performed more than 70 cases of EUS-FNA involving pancreatobiliary tumor prior to this case in our hospital. The $22 \mathrm{G}$ ProCore needle used in our procedure is a well-known popular needle with proven safety, feasibility, and diagnostic yield. ${ }^{12}$

As observed in our case, the delayed massive bleeding after the therapeutic and diagnostic procedure was attributed to bleeding from iatrogenic pseudoaneurysm. ${ }^{13,14}$ Hemorrhage from major ampulla caused by ruptured aneurysm of the pancreatic head after EUS-FNA was strongly suggestive of hemosuccus pancreaticus (HP) ${ }^{15,16} \mathrm{HP}$ was first reported in 1931 and is a rare cause of acute gastrointestinal bleeding usually occurring as a complication of acute or chronic pancreatitis in chronic alcohol ingestion. The splenic artery is the most involved site (more than 60\%) and other etiologies of HP were tumor, vascular anomalies, iatrogenic disease after the procedure, and congenital abnormalities. ${ }^{15}$ This case was attributed to mostly iatrogenic direct vascular injury after EUS-FNA, which contributed to the formation of gastroduodenal artery pseudoaneurysm and delayed massive bleeding. A similar case report of HP caused by EUS-FNA was selflimited and resolved spontaneously. ${ }^{17}$ Iatrogenic pseudoaneurysmal bleeding after major surgery leads to blood collection 
at various sites including peritoneal and retroperitoneal space or surrounding pancreas. Rupture of the pseudoaneurysm, although uncommon, causes life-threatening sentinel bleeding to prevent major hemorrhage. Therefore, recognition of the sentinel bleeding sign and prompt intervention via angiographic embolization are life-saving measures. ${ }^{13,14}$

Treatment of iatrogenic ruptured pseudoaneurysmal bleeding involves two main options: angiographic embolization and surgery. Angiography is the initial treatment choice and surgery is indicated for hemodynamic instability, and uncontrolled hemorrhage after angiographic embolization. In our case, attempted cannulation of pancreatic duct was not possible and another insertion of covered biliary metal stent over previously two plastic stents partially blocked the hemorrhage from major ampulla and mildly increased the interval of bleeding and decreased the bleed volume. Previous reports of bleeding management after EUS-FNA mostly involved conservative measures, and transfusions in a small number of cases. ${ }^{1,3}$

In summary of our case, the presence of iatrogenic gastroduodenal artery pseudoaneurysm in pancreatic head was detected in the follow-up CT examination during an outpatient visit after EUS-FNA based on a sentinel bleeding sign involving a single episode of tarry stool after discharge. Following admission to intensive care unit, we promptly explained the cause of delayed bleeding and successfully treated the patient's massive bleeding using percutaneous arterial embolization.

\section{요 약}

내시경 초음파 유도 가는 바늘 생검은 췌담도 질환의 진단 영역에서 잘 알려진 안전한 시술이다. 심각한 천공, 췌장염, 출혈, 감염의 합병증은 드물게 보고되고 있다. 시술 후에 발생한 지연성 출혈의 보고는 매우 드물고, 시술 후 가성 동맥류으로 인한 지연성 출혈의 보고는 저자가 알기로는 없는 것으로 알고 있다. 저자는 췌장의 고형성 병변에 대한 내시경 초음파 가는 바늘 생검 후에 발생한 위십이지장 동맥 가성 동맥류로 인한 지연성 출혈을 보고한다. 68세 남자 환자가 췌장두부에 $15 \mathrm{~mm}$ 가량의 종양으로 시술 10 일 후에 흑색변을 주소로 재방문
하였다. 당시 복부 전산화단층촬영을 시행하였고, $2 \mathrm{~cm}$ 가량의 조영증강의 둥근 병변이 췌장의 두부에서 확인되었고, 조직 검사 결과는 악성을 시사하지 않았다. 환자에게 추가 검사를 위하여 입원을 권유하였으나 거부하였다. 12 일 후에 환자는 반복되는 흑색변을 주소로 응급실에 재방문하였다. 혈관조 영술에서 위십이지장동맥 가성동맥류 소견 및 코일 색전술 을 시행한 후 성공적으로 지혈하였다. 환자는 유문 보존 췌십이 지장 절제술을 받았고, 병기는 IIB 췌장암으로 진단되었다.

국문 색인: 위장관 출혈, 췌장종양, 내시경 초음파 유도 가는 바늘 생검, 가성 동맥류, 위십이지장동맥

\section{Conflicts of Interest}

The authors have no conflicts to disclose.

\section{REFERENCES}

1. Lee KH, Kim EY, Cho J, et al. Risk factors associated with adverse events during endoscopic ultrasound-guided tissue sampling. PLoS One 2017;12:e0189347.

2. Rodríguez-D'Jesús A, Fernández-Esparrach G, Marra-Lopez C, et al. Adverse events of EUS-guided FNA of pancreatic cystic and solid lesions by using the lexicon proposed in an ASGE workshop: a prospective and comparative study. Gastrointest Endosc 2016;83:780-784.

3. Hamada T, Yasunaga H, Nakai $Y$, et al. Severe bleeding and perforation are rare complications of endoscopic ultrasound-guided fine needle aspiration for pancreatic masses: an analysis of 3,090 patients from 212 hospitals. Gut Liver 2014;8:215-218.

4. Iglesias-Garcia J, Lariño-Noia J, Domínguez-Muñoz JE. When to puncture, when not to puncture: Pancreatic masses. Endosc Ultrasound 2014;3:91-97.

5. But DY, Poley JW. To fine needle aspiration or not? An endosonographer's approach to pancreatic cystic lesions. Endosc Ultrasound 2014;3:82-90.

6. Mekky MA, Abbas WA. Endoscopic ultrasound in gastroenterology: from diagnosis to therapeutic implications. World J Gastroenterol 2014;20:7801-7807.

7. Costache MI, Iordache S, Karstensen JG, Săftoiu A, Vilmann P. Endoscopic ultrasound-guided fine needle aspiration: from the past to the future. Endosc Ultrasound 2013:2:77-85.

8. Wang $K X$, Ben $Q W$, Jin ZD, et al. Assessment of morbidity and mortality associated with EUS-guided FNA: a systematic review. Gastrointest Endosc 2011;73:283-290.

9. Katanuma A, Maguchi $H$, Yane K, et al. Factors predictive of adverse events associated with endoscopic ultrasound-guided fine needle 
aspiration of pancreatic solid lesions. Dig Dis Sci 2013;58:2093-2099.

10. Ge N, Zhang $S$, Jin Z, et al. Clinical use of endoscopic ultrasoundguided fine-needle aspiration: guidelines and recommendations from Chinese society of digestive endoscopy. Endosc Ultrasound 2017;6:75-82.

11. Fujii LL, Levy MJ. Basic techniques in endoscopic ultrasound-guided fine needle aspiration for solid lesions: adverse events and avoiding them. Endosc Ultrasound 2014;3:35-45.

12. Alatawi A, Beuvon F, Grabar S, et al. Comparison of $22 \mathrm{G}$ reversebeveled versus standard needle for endoscopic ultrasound-guided sampling of solid pancreatic lesions. United European Gastroenterol J 2015;3:343-352.

13. de Castro SM, Kuhlmann KF, Busch OR, et al. Delayed massive hemorrhage after pancreatic and biliary surgery: embolization or surgery?
Ann Surg 2005;241:85-91.

14. Schäfer M, Heinrich S, Pfammatter T, Clavien PA. Management of delayed major visceral arterial bleeding after pancreatic surgery. HPB (Oxford) 2011;13:132-138.

15. Han B, Song ZF, Sun B. Hemosuccus pancreaticus: a rare cause of gastrointestinal bleeding. Hepatobiliary Pancreat Dis Int 2012;11:479488.

16. Lee YJ, Hyun JJ, Choi JH, et al. Hemosuccus pancreaticus due to intraductal pseudoaneurysm. Korean J Pancreas Biliary Tract 2016;21:4044.

17. Singh P, Gelrud A, Schmulewitz N, Chauhan S. Hemosuccus pancreaticus after EUS-FNA of pancreatic cyst (with video). Gastrointest Endosc 2008;67:543. 